\title{
The Ecology of Charophyte Algae (Charales) ${ }^{1}$
}

\author{
Maximiliano Barbosa, Forrest Lefler, David E. Berthold, and H. Dail Laughinghouse IV ${ }^{2}$
}

\section{Abstract}

Charophytes are a group of green algae within the order Charales. These algae are macroscopically similar to aquatic vascular plants and are typically grouped with aquatic weeds because their excessive growth in some locations can be considered a nuisance. Charophytes are ecologically important in their ecosystems because they help control nutrient cycles, improve water clarity, provide important food sources for water birds and fish, and serve as bioindicators of ecosystem status. In Florida, the genera Nitella and Chara make up the majority of the diversity of the Charales, where both are known to provide important ecosystem services and act as occasional nuisance species. This document provides an overview of charophyte ecology, habitat requirements, and status in the state of Florida. Guidelines for species identification of Chara are also outlined.

\section{Introduction}

Charophytes are a group of green algae belonging to the order Charales. They include extant and fossil members of the order, in addition to members of the extinct orders Sycidiales and Moellerinales (Schneider et al. 2015). The charophytes include multicellular macroalgae that are morphologically similar to vascular plants and were previously described as the algae most closely related to vascular plants. However, phylogenetic and genomic analyses have determined that freshwater lineages of the Zygnematophyceae (also known as Desmidiales or Zygnematales) are the true sister group of terrestrial plants (Delwiche and Cooper 2015; Jiao et al. 2020).

Charophytes are endemic to freshwater habitats, with some exceptions (Garcia and Chivas 2006). They can cover the bottoms of lakes, slow-flowing rivers, and streams and are anchored to sediment by rhizoids (Wehr et al. 2015). Within these habitats, many taxa accumulate encrustations of calcium carbonate in the form of calcite on their surfaces, a characteristic which has given them the name "stonewort." Some species produce distinct, strong, musty odors, which have given them other common names, including "muskgrass" and "skunkweed." Charalean algae are well adapted to grow in sand or silt beds, and in lakes or ponds rich in marl sediment where they can form extensive submerged "meadows" (Figure 1). These meadows dominated by charophyte algae tend to have low phytoplankton production, often resulting in very clear water (Wehr et al. 2015).

Within these algal meadows, individual plants, such as Chara, can reach various heights depending on water depth and light intensity; some taxa in the Charales can reach lengths greater than 1 meter. Using Chara as a model organism, the basic charalean morphology consists of an erect central stem or "axis" differentiated into long, unicellular internodal cells and short multicellular nodes (Figures 1-3). Throughout the stem, whorls of branchlets (or branches) originate laterally at regular intervals. The group typically has branched filaments, where the main axis (thallus) is

1. This document is SS-AGR-448, one of a series of the Agronomy Department, UF/IFAS Extension. Original publication date January 2021. Visit the EDIS website at https://edis.ifas.ufl.edu for the currently supported version of this publication.

2. Maximiliano Barbosa, graduate research assistant, Agronomy Department; Forrest Lefler, graduate research assistant, Interdisciplinary Ecology Program; David E. Berthold, biological scientist III; and H. Dail Laughinghouse IV, assistant professor, Agronomy Department; UF/IFAS Fort Lauderdale Research and Education Center, Davie, FL 33314.

The Institute of Food and Agricultural Sciences (IFAS) is an Equal Opportunity Institution authorized to provide research, educational information and other services

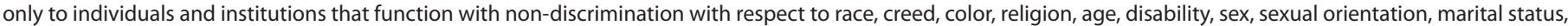

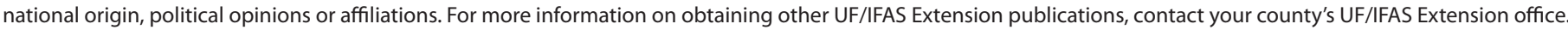
U.S. Department of Agriculture, UF/IFAS Extension Service, University of Florida, IFAS, Florida A \& M University Cooperative Extension Program, and Boards of County Commissioners Cooperating. Nick T. Place, dean for UF/IFAS Extension. 
differentiated at the apex, nodes, and basal region. The basal region consists of colorless rhizoidal branches, which are used for attachment to muddy or silty substrates. The rhizoids of these algae do not uptake nutrients; rather, these algae translocate nutrients from the water column via cell-to-water interface (Perez et al. 2014).

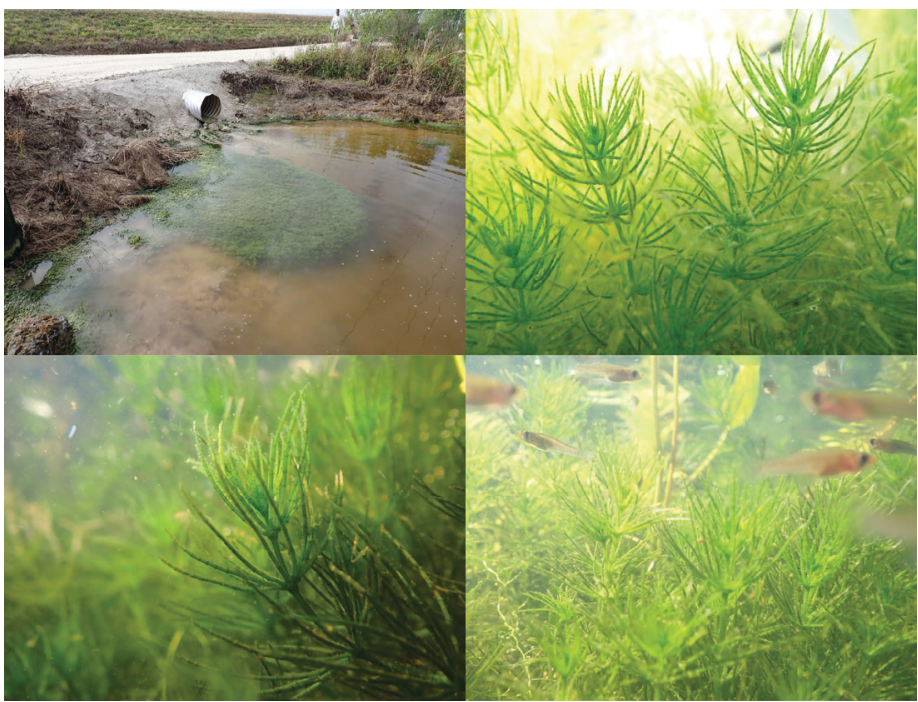

Figure 1. Images of Chara in the field, including large beds that create underwater habitats for aquatic life.

Credits: E. Becks and D. E. Berthold

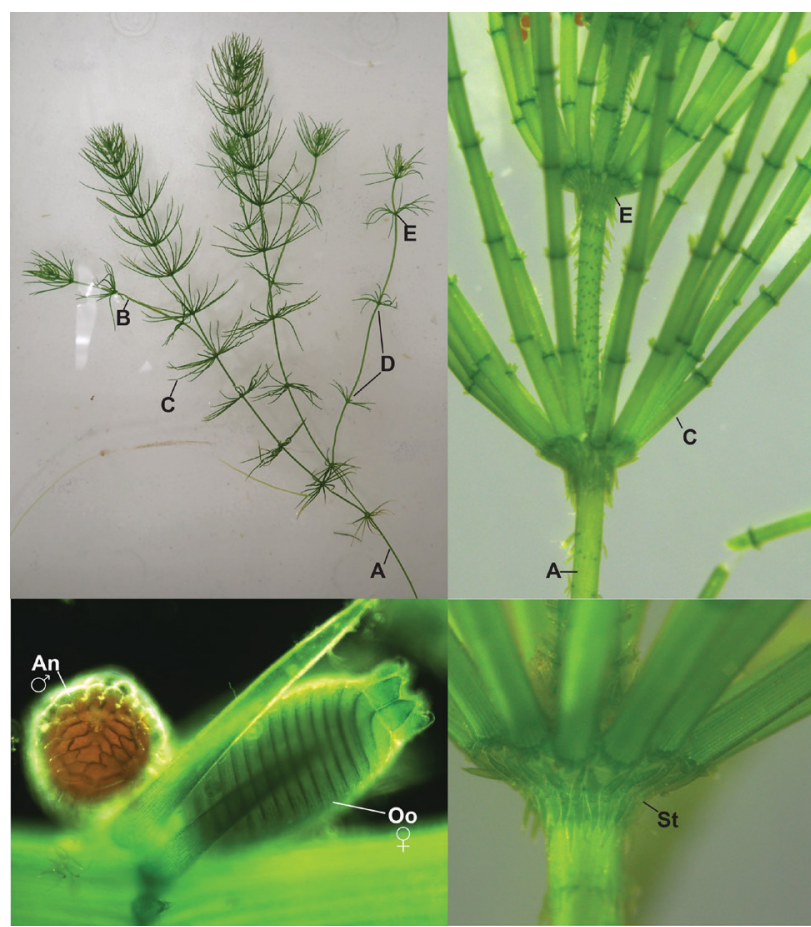

Figure 2. (Top left to right) The basic morphology of Chara, including the main stem or axis (A), branches (B), whorl of branchlets (C), internode (D), and the nodes (E). (Bottom left to right) Male and female reproductive structures in Chara, including the female oogonium (Oo) and the male antheridium (An). Stipulodes (St) morphology is often a method used to identify species. Credits: D. E. Berthold
Charophytes propagate asexually or reproduce sexually. Asexual vegetative growth occurs through plant fragmentation and amylum star (propagative body) or bulbil formation. For example, Chara can also reproduce through the development of new vegetative shoots from rhizoids. Sexually reproductive plants occur as monoecious (both sexes occurring in one plant) or dioecious (sexes occurring in separate plants) individuals. As with land plants, charophytes have conspicuous sexual structures: antheridia (male), where spermatozoids develop, and oogonia (female), each containing a single egg cell (Figure 2) (Wehr et al. 2015).

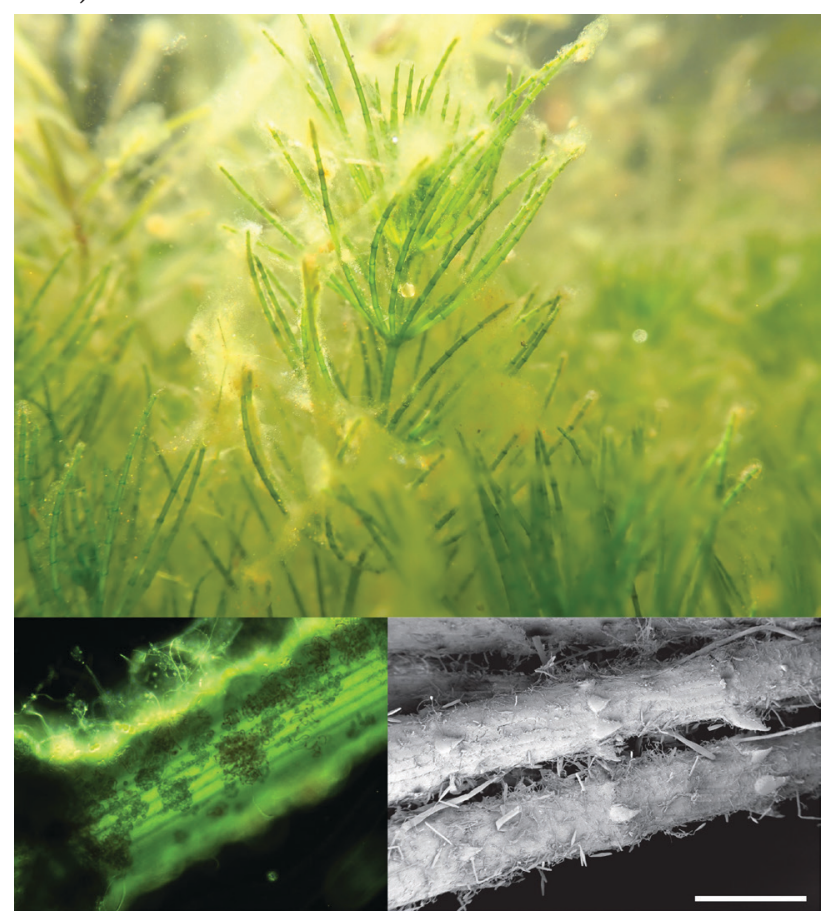

Figure 3. Chara plants in the field are usually found covered with epiphytic aquatic organisms that only microscope methods such as bright-field microscopy (bottom left) or scanning electron microscopy can reveal.

Credits: D. E. Berthold

The antheridia in the Charales are bright orange when mature and are visible with the naked eye (Figure 2). As oogonia develop, they form elongated cells, known as tube cells (or sheath cells) that grow upward along the surface of the egg, keeping pace with the enlargement of the egg. As the egg reaches maturity, openings form between the tube cells, which allow the sperm to fertilize the egg (Caisova and Gabka 2009).

Only three of the six genera of charophytes are found in North America, including Chara, Nitella, and Tolypella (Perez et al. 2014). Twelve species of Tolypella, more than 30 species of Nitella, and 27 species of Chara have been registered in the United States (Scribailo and Alix 2010). The genera Chara and Nitella are widespread throughout 
Florida. In the field, Chara can often be mistaken for Nitella or coontail (Ceratophyllum demersum L.) due to superficial similarities in morphology. Although the genus Chara is the richest in species number within the order, species discrimination is complicated. Morphological identification is based on features of the stem-such as length and number of spine cells, length of stipulodes (needle-shaped structures), and cortication-and reproductive structures, and many of these features overlap among species. Two species of Chara abound in south Florida waters-Chara haitensis Turpin and C. zeylanica Klein ex Willdenow-and their morphology is very similar. The main differences between them are that $C$. haitensis has longer lengths, larger stem diameters, and longer branches than $C$. zeylanica. Visually, C. haitensis appears longer and finer, while $C$. zeylanica appears shorter with more pointed branchlets (Figure 4). Because Chara species are morphologically similar, simultaneous morphological and genetic analyses are warranted for more reliable identification.

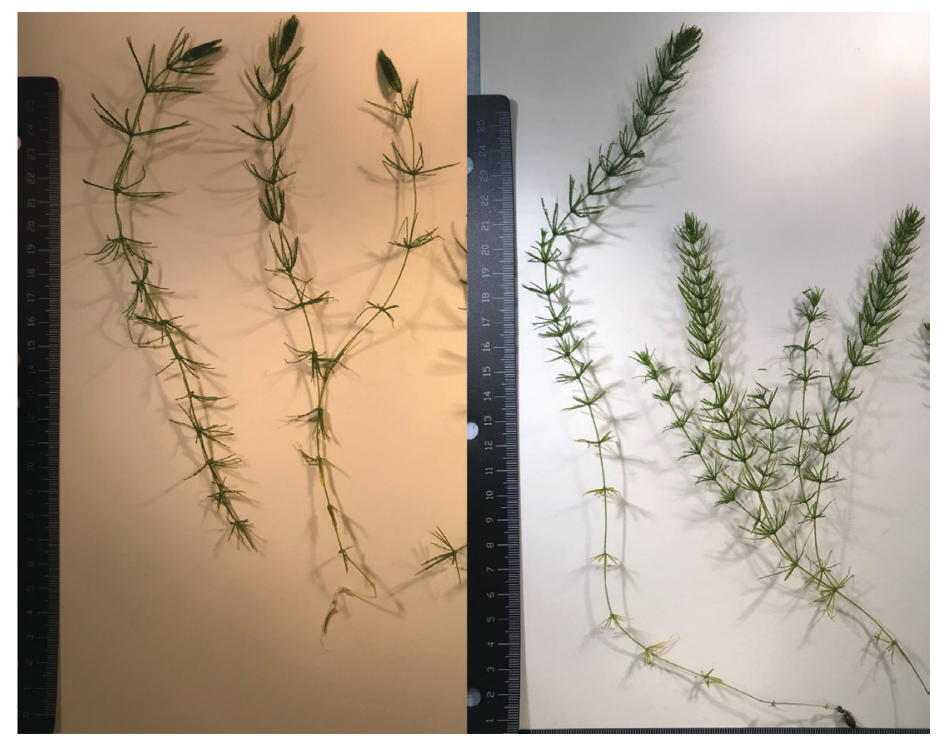

Figure 4. Chara plants. Left: Chara zeylanica. Right: C. haitensis. Credits: D. E. Berthold

Charophytes occur in all depths within the photic (sunlit) zone and are mostly found in fresh waters. While some taxa can tolerate hypersaline waters (i.e., Lamprothamnium spp.) (Garcia and Chivas 2004), they are not readily present in fully marine environments. In addition, these macroalgae are present on all continents except Antarctica, including some Arctic and high mountain regions, occurring in natural and artificial lotic (running water) and lentic (standing water) habitats (Schneider et al. 2015). Although most species of the order Charales inhabit oligotrophic (nutrient-poor) waters, some species can tolerate eutrophic (nutrient-rich) conditions of high productivity (Pennin et al. 2008). However, since most charophytes are not found in nutrient-rich waters, they are among the first submerged macroalgae to disappear during the eutrophication process. These algae are also common in shallow calcareous lakes of mineral-rich waters and oligotrophic conditions. Under optimal conditions, some shallow lakebeds reach a biomass of more than 400 grams (dry weight) per square meter (Figures 1 and 3) over a few months (Fernandez-Aláez et al. 2002).

Charophytes are ecologically important. They can establish dense biomass in both deep and shallow lakes and ponds, depending on water clarity. These massive growths are important food for herbivorous waterfowl (Schmieder et al. 2006) and feed for aquatic animals and farm livestock. They also have functions in water purification and fish farming (Schneider et al. 2015). These beds are important breeding areas for fish because they offer protection from predators and currents (Figure 1) (Lake et al. 2002).

Charophyte beds are good bioindicators of ecosystem status because they are sensitive to environmental changes. For example, Chara play an important role in carbon and nutrient cycles, especially nitrogen and phosphorus, because they improve water clarity and maintain oligotrophic conditions in ecosystems. Charophytes can absorb nutrients from the water into the plant biomass, improve sedimentation, and reduce sediment suspension, which helps control nutrient cycles (Vermaat et al. 2000). Charophyte biomass has also been used as fertilizer in the past. Between the $18^{\text {th }}$ and $20^{\text {th }}$ centuries, charophytes were harvested from Lake Constance in Germany and used as fertilizer in vegetable fields (Schneider et al. 2015). Many species are perennial, and their biomass decomposes slowly, allowing carbon and nutrients to be stored for long periods in their bed sediments. Over the past few million years, these algae have been important producers of carbonate sediments in freshwater lakes, because they may be more heavily encrusted with calcium carbonate than aquatic vascular plants (Rodrigo et al. 2010). Although charophyte meadows are considered advantageous for an ecosystem, they are sometimes seen as a nuisance. They can obstruct canals and reservoirs if growth is not properly controlled.

Charophytes provide a multitude of economic services. Such services include enhancement of water quality, storage of carbon and nutrients, fish farming, food for aquatic animals and farm livestock, fertilizers, and much more. Therefore, a better understanding of the ecology of this group of algae is important for the conservation and restoration of aquatic ecosystems. 


\section{References}

Caisova, L., and M. Gąbka. 2009. "Charophytes (Characeae, Charophyta) in the Czech Republic: Taxonomy, Autecology and Distribution." Fottea 9 (1): 1-43. https://doi. org/10.5507/fot.2009.001

Delwiche, C. F., and E. D. Cooper. 2015. "The Evolutionary Origin of Terrestrial Flora." Current Biology 25:R899-R910. https://doi.org/10.1016/j.cub.2015.08.029

Fernández-Aláez, M., C. Fernández-Aláez, and S. Rodrıguez. 2002. "Seasonal Changes in Biomass of Charophytes in Shallow Lakes in the Northwest of Spain." Aquatic Botany 72 (3-4): 335-348.

García, A., and A. R. Chivas. 2004. "Quaternary and Extant Euryhaline Lamprothamnium Groves (Charales) from Australia: Gyrogonite Morphology and Paleolimnological Significance." Journal of Paleolimnology 31 (3): 321-341. https://doi.org/10.1023/B:JOPL.0000021725.32489.bd

Jiao, C., I. Sorensen, X. Sun, H. Sun, H. Behar, S. Alseekh, G. Philippe, et al. 2020. "The Penium margaritaceum Genome: Hallmarks of the Origin of Land Plants." Cell 181:1097-1111. https://doi.org/10.1016/j.cell.2020.04.019

Lake, M. D., B. J. Hicks, R. D. S. Wells, and T. M. Dugdale. 2002. "Consumption of Submerged Aquatic Macrophytes by Rudd (Scardinius erythrophthalmus L.) in New Zealand." Hydrobiologia 470:13-22. https://doi. org/10.1023/A:1015689432289

Penning, W. E., M. Mjelde, B. Dudley, S. Hellsten, J. Hanganu, A. Kolada, M. Berg, and F. Ecke. 2008. "Classifying Aquatic Macrophytes as Indicators of Eutrophication in European Lakes." Aquatic Ecology 42 (2): 237-251. https:// doi.org/10.1007/s10452-008-9182-y

Perez, W., J. D. Hall, R. M. McCourt, and K. G. Karol. 2014. "Phylogeny of North American Tolypella (Charophyceae, Charophyta) Based on Plastid DNA Sequences with a Description of Tolypella ramosissima sp. nov." Journal of Phycology 50 (5): 776-789. https://doi.org/10.1111/ jpy. 12219

Rodrigo, M. A., J. L. Alonso-Guillén, and I. Soulié-Märsche. 2010. "Reconstruction of the Former Charophyte Community out of the Fructifications Identified in Albufera de València Lagoon Sediments." Aquatic Botany 92 (1): 14-22. https://doi.org/10.1016/j.aquabot.2009.09.002
Schmieder, K., S. Werner, and H. G. Bauer. 2006.

"Submersed Macrophytes as a Food Source for Wintering Waterbirds at Lake Constance." Aquatic Botany 84 (3): 245-250. https://doi.org/10.1016/j.aquabot.2005.09.006

Schneider, S. C., A. García, C. Martín-Closas, and A. R. Chivas. 2015. "The Role of Charophytes (Charales) in Past and Present Environments: An Overview." Aquatic Botany 120:2-6. https://doi.org/10.1016/j.aquabot.2014.10.001

Scribailo, R. W., and M. S. Alix. 2010. "A Checklist of North American Characeae." Charophytes 2 (1): 38-52.

Vermaat, J. E., L. Santamaria, and P. J. Roos. 2000.

"Water Flow across and Sediment Trapping in Submerged Macrophyte Beds of Contrasting Growth Form." Archiv für Hydrobiologie 148 (4): 549-562. https://doi.org/10.1127/ archiv-hydrobiol/148/2000/549

Wehr, J. D., R. G. Sheath, and J. P. Kociolek (Eds.). 2015. Freshwater Algae of North America: Ecology and Classification, $2^{\text {nd }}$ edition. London: Elsevier. 